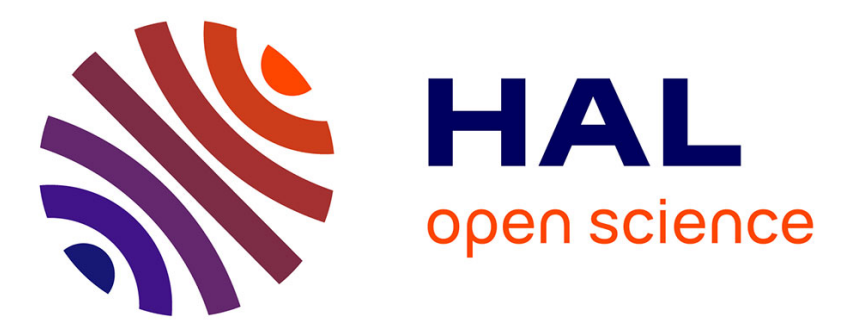

\title{
Agronomic model uses to predict cultivar performance in various environments and cropping systems. A review
}

Marie-Helene Jeuffroy, Pierre Casadebaig, Philippe Debaeke, Chantal Loyce, Jean Marc Meynard

\section{- To cite this version:}

Marie-Helene Jeuffroy, Pierre Casadebaig, Philippe Debaeke, Chantal Loyce, Jean Marc Meynard. Agronomic model uses to predict cultivar performance in various environments and cropping systems. A review. Agronomy for Sustainable Development, 2014, 34 (1), pp.121-137. 10.1007/s13593-0130170-9 . hal-01173293

\section{HAL Id: hal-01173293 \\ https://hal.science/hal-01173293}

Submitted on 28 May 2020

HAL is a multi-disciplinary open access archive for the deposit and dissemination of scientific research documents, whether they are published or not. The documents may come from teaching and research institutions in France or abroad, or from public or private research centers.
L'archive ouverte pluridisciplinaire HAL, est destinée au dépôt et à la diffusion de documents scientifiques de niveau recherche, publiés ou non, émanant des établissements d'enseignement et de recherche français ou étrangers, des laboratoires publics ou privés. 


\title{
Agronomic model uses to predict cultivar performance in various environments and cropping systems. A review
}

\author{
Marie-Hélène Jeuffroy • Pierre Casadebaig • \\ Philippe Debaeke • Chantal Loyce • Jean-Marc Meynard
}

Accepted: 9 July 2013 / Published online: 2 August 2013

(C) INRA and Springer-Verlag France 2013

\begin{abstract}
The diversity of growing conditions and the development of new outlets for agricultural products favour a diversity of crop management systems requiring various cultivars, with specific characteristics. Genotype performance is usually assessed through multi-environment trials comparing a variable number of genotypes grown in a wide range of soils, climatic conditions and cropping systems. Field experiments show empirical evidence for the interactions between genotype, environment and cropping system. However, such interactions are rarely taken into account to design ideotypes or for cultivar assessment, or in the definition of crop management plans adapted to cultivars. Agronomic models, built to simulate the dynamic response of crops to their environment, and thus to techniques which modify it, appear to be appropriate tools to evaluate and predict these interactions. This paper reviews the three main uses of model-based predictions of the interactions between genotype, environment and cropping system: definition of breeding targets, characterisation of the environments in cultivar experiments and support for the choice of the best cultivar to grow in a given situation. Models specifically allow understanding the influence of one or a combination
\end{abstract}

M.-H. Jeuffroy $(\varangle) \cdot$ C. Loyce

INRA, UMR211 Agronomie, Bâtiment EGER,

F-78850 Thiverval-Grignon, France

e-mail: Marie-Helene.Jeuffroy@grignon.inra.fr

M.-H. Jeuffroy • C. Loyce

AgroParisTech, UMR211 Agronomie, F-78850

Thiverval-Grignon, France

P. Casadebaig $\cdot$ P. Debaeke

INRA, UMR1248 AGIR, F-31326 Castanet Tolosan, France

J.-M. Meynard

INRA, UAR1218 Département SAD, F-78850 Thiverval-Grignon,

France of specific traits on performances and long-term ecological impacts. We show that a diversity of models is required, from physiologically based crop models to agroecology-based cropping system or landscape models, able to account well for farmers' practices. A way of taking cultivars into account in crop models is proposed, based on three main steps: the choice of the model, the identification and estimation of its cultivar parameters, and testing the model for decision support. Finally, the analysis of the limitations for wider use of crop models in variety breeding and assessment addresses some major questions for future research.

Keywords Genotype-environment-management interaction - Crop management · Cropping system . Simulation model · Genotype-dependent parameter . Ideotype $\cdot$ Cultivar assessment $\cdot$ Multi-environment trials

Contents

1. Introduction

2. Diversity in using model-based predictions of the interaction between genotype, environment and cropping system

2.1. The use of model-based predictions for defining breeding targets

2.1.1. The limits of breeding without models

2.1.2. Use of crop models to simulate the impact of a cultivar character (or trait) on production

2.1.3. Limitations of crop models as breeding support tools

2.1.4. Use of cropping system models to simulate the effects of cultivar traits on medium- and longterm ecological impacts

2.2. The use of agronomic models for analysing variety trials

2.2.1. Characterisation and typology of the field environments over an experimental network 
2.2.2. Breaking down the genotype-environment interaction

\subsubsection{Carrying out virtual experiments}

2.3. The use of agronomic models for defining the management and environmental targets for each cultivar

2.3.1. Choice of the cultivar for given conditions of soil and weather

2.3.2. Choice of the combination of cultivar and crop management system

3. A method to take into account the cultivar in crop models

3.1. Which models give a good account of the interaction between genotype, environment and cropping system?

3.1.1. Complexity level of the models

3.1.2. Processes involved in the model

3.2. How to identify and estimate the cultivar parameters?

3.2.1. Which parameters vary among genotypes?

3.2.2. Estimation of the genotype-dependent parameters

3.3. Evaluation of the model quality for decision support in cultivar and crop management choices

3.3.1. Predicting cultivar performance in various environments with the same management

3.3.2. Predicting cultivar performances in various crop management systems

3.3.3. Value of the evaluation of decisional quality

4. Conclusion

\section{Introduction}

The diversity of environmental conditions among locations and the development of new outlets for agricultural products (various quality targets, non-food channels etc.) favour a diversity of crop management systems requiring different cultivar choices. In the future, as mentioned by Meynard and Jeuffroy (2002), genetic progress will be measured less by an increase in the average performance of the cultivar, as currently (e.g. Vear et al. 2003), than by an improvement of the adaptation of cultivars to the diversity of cropping environments, market requirements and type of agriculture. Lecomte et al. (2010) suggested that breeders and distributors of new cultivars are aware of the need to improve their ability to evaluate new varieties for these conditions, in order to forecast, as early as the breeding phase, their response to various environments and crop management.

The assessment and the prediction of the response of genotypes is generally done through networks of multienvironment trials comparing several genotypes (Fig. 1) grown in a wide range of soils, climatic conditions and cropping systems. In these networks, a large interaction between genotypes and growing conditions is often observed, representing $10-25 \%$ of the total yield variance, and similar in size to the main effect of the genotype (e.g. wheat: Baril 1992, Brancourt-Hulmel et al. 1997; pea: Biarnès-Dumoulin et al. 1996; soybean: Desclaux 1996; corn: Argillier et al. 1994; van Eeuwijk et al. 1995; EpinatLe Signor et al. 2001; sunflower: Foucteau et al. 2001). As shown by Brancourt-Hulmel et al. (1999), this genotypeenvironment interaction can also be explained by numerous variables related to the crop management (sowing date, nitrogen fertilisation, crop protection and irrigation). Various statistical methods have been proposed to analyse and predict the genotype-environment interaction (BrancourtHulmel et al. 1997). They are generally used to forecast the effect of climatic variables on the cultivar response, but rarely to predict their performance in various crop management conditions, and never to predict the consequences of various crop sequences, cultivar frequencies or spatial location of cultivars on genotype performance. Thus, it is difficult to use the results of multi-environment trials to choose cultivars which are the best suited to a particular crop management system, crop sequence or geographical location; nor do they provide useful information to design the crop management system best suited to a given genotype, which is known to differ from cultivar to cultivar (Loyce et al. 2008). Finally, they have a low predictive capacity, particularly for environments and cropping systems not represented in the trials, for instance low-input conditions or drought-prone environments.

Crop models, built to simulate the dynamic response of crops to their environment and hence to techniques which modify it, have now matured to the point where they can be used for numerous applications. Using them for the evaluation of genotypes was proposed some time ago (Whisler et al. 1986), but it is only in the last 15-20 years that several

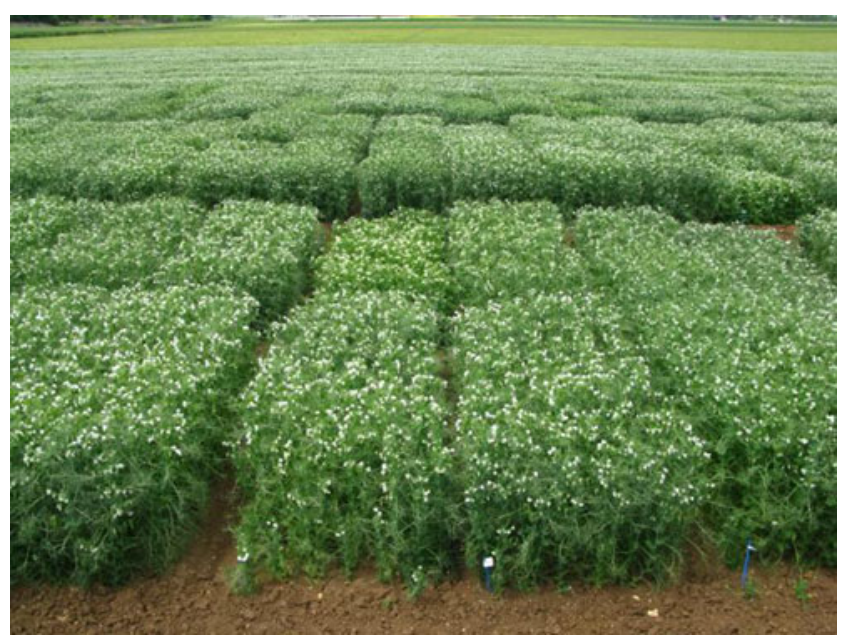

Fig. 1 An example of cultivar trial for pea: several genotypes are grown in a same environment. Multi-environment trials, located in various sites, are the main tool of breeders to assess the performances of genotypes under breeding 
studies have been carried out in this field (e.g. Shorter et al. 1991; Boote et al. 1996; Cooper and Hammer 1996; Hammer et al. 2010). Several papers have reviewed the possible uses of dynamic crop models for breeding and, in a less informative way, for cultivar advice (Boote et al. 2001; Matthews 2002; Hammer et al. 2003; Jeuffroy et al. 2006; Messina et al. 2006). More recently, other models, such as spatially explicit models simulating gene flow, have been used to guide breeding and cultivar evaluation (Fargue et al. 2005, 2006). Models appear as new tools supporting or replacing experiments (they are used to do 'virtual' experiments) to evaluate and predict the interaction between genotype, environment and cropping system interaction (Shorter et al. 1991; Cooper and Hammer 1996; Jeuffroy et al. 2006).

This paper reviews the actual and potential uses of agronomic models to predict cultivar performance in various environments and cropping systems. In the first part we will identify the different types of uses and related questions. Then we will describe the specific steps when developing and using an agronomic model with cultivar-specific parameters in order to analyse and predict the genotype's behaviour in various environments and cropping systems and for various objectives.

\section{Diversity in using model-based predictions of the interaction between genotype, environment and cropping system}

Three main types of uses of model-based predictions of the interaction between genotype, environment and cropping system can be identified in the literature (Fig. 2):

- $\quad$ Refining the definition of breeding targets, i.e. identifying the phenological, morphological and physiological traits to breed for a given aim and environment/cropping system (ideotyping)

- Refining the analysis of multi-environment cultivar trials, by characterising the environments in order to optimise networks, and understand the interactions between genotype, environment and cropping system that are observed in networks (agronomic diagnosis)

- Helping in the use of new cultivars, by supporting the choice of the best cultivar to grow in a given cropping system, and/or a given environment (cultivar choice)

2.1 The use of model-based predictions for defining breeding targets

\subsubsection{The limits of breeding without models}

Because of the low heritability of yield, breeders use indirect criteria, such as morphological or physiological traits, considered as good predictors for yield. However, these criteria are not always chosen with respect to their importance for crop behaviour, which can sometimes lead to targeting errors. For example, among the numerous physiological criteria proposed to improve drought resistance, few benefit yield in dry conditions. Richards (1996) proposed several hypotheses to explain this lack of success: (1) the criteria may be more linked to survival than to productivity under drought, (2) they may have significant effects only during short periods of drought or for isolated plants, but few on crop growth and final yield, (3) these criteria may be useful only in particular weather conditions or cropping systems, but not over the whole range of target environments.

Agronomic models, making possible a rapid and multicriteria evaluation of genotypic traits in interaction with various environmental conditions, can reduce these problems. Varying the value of one trait (while keeping the others constant) amounts to a virtual comparison of isogenic lines, yet with far fewer methodological difficulties than are encountered in field experiments (Reymond 2001; Matthews 2002). Sensitivity analysis of the model to the studied trait makes it possible to quantify its particular influence on crop
Fig. 2 Diversity of uses of model-based predictions of the interaction between genotype, environment and cropping system

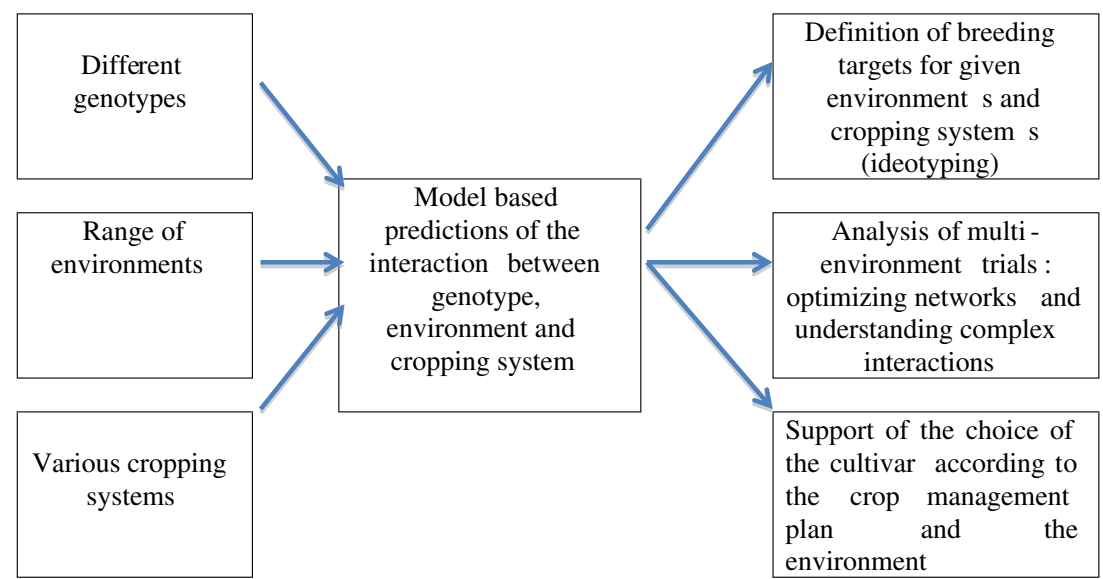


performance in various environments and cropping systems. Models thus allow (1) traits (or combinations of traits) to be identified which are interesting to breed for, that is the definition of ideotypes (Donald 1968; Sedgley 1991) and (2) virtual cultivars to be designed and assessed, based on interesting characteristics combinations outside the range of values available in the genetic resources (Fargue et al. 2005, 2006).

\subsubsection{Use of crop models to simulate the impact of a cultivar character (or trait) on production}

The literature contains numerous examples of the use of crop models for analysing the effect of various physiological traits on crop yield. For example, with the model ORYZA1, Aggarwal et al. (1997) evaluated the influence of several genotypic traits in maximising rice yield in a dry tropical season. They conclude that when nitrogen nutrition can be improved without increasing lodging or diseases, the best ideotype for these conditions would combine a large reproductive sink, high nitrogen concentrations in the leaves and a long seed-filling period. For rainfed maize and sorghum, Muchow et al. (1991) analysed the consequences for yield of a higher water uptake by the root system vs a higher water use efficiency (WUE). Their simulations showed that the earlier water uptake leads to yield loss because the soil water reservoir does not refill in 20-25\% of the situations. The effect of a WUE increase appeared dependent on its link with the radiation use efficiency (RUE): if the WUE increase is accompanied by a RUE decrease, the risk of yield loss is $30 \%$; if the RUE is stable or increases, a yield increase is observed every year. Another example concerns the use of the OILCROP-SUN model to assess the importance of early vigour on sunflower as a function of sowing date, cultivar earliness and soil depth (Agüera et al. 1997).

Different authors (Asseng et al. 2002 and Semenov et al. 2009 for wheat; Casadebaig et al. 2008 for sunflower) used crop models to simulate the potential interest of a range of morpho-physiological traits in different climatic environments. As an example, Casadebaig et al. (2008) used the SUNFLO crop model to assess the effect of three phenotypic traits (length of maturation phase, potential leaf area and stomatal regulation) on yield at three sites in France over a range of 35 annual weather patterns. The model confirmed that early-maturing genotypes with early stomatal closure should be grown in drought-prone environments, whereas a large leaf area and a late maturity date should be more beneficial in low-stress environments. Weather variability would have a big effect on the impact of a trait on yield: for example, the effect of early stomatal closure is always beneficial, but weather variability might eliminate or double its mean effect on yield.
However, yield differences between lines often result from several traits that interact. It is thus interesting, for breeding support, to evaluate the consequences of a simultaneous change in several traits: crop models may be used to design crop ideotypes (a collection of traits) for target environments as was illustrated by Casadebaig et al. (2011) on sunflower, Jeuffroy et al. (2012) on pea or Suriharn et al. (2011) on peanut.

\subsubsection{Limitations of crop models as breeding support tools}

The limitations of the use of crop models to identify breeding targets are linked to some of their weak points:

- A crude representation of environments and cropping systems. Numerous environmental conditions known to have effects on yield are not represented in crop models, such as airborne diseases, excess water, soil compaction or weather factors inducing pollen sterility. These last factors have frequently been identified by Lecomte (2005) as limiting yield for small grain cereals and explaining part of the genotype-environment interaction. Some models take them into account. For example, BETHA (Loyce et al. 2002a) simulates the effects of the main airborne diseases of wheat. In this model, parameters representing varietal resistance to the various diseases allow the interaction between genotype and disease pressure to be simulated, thus giving a good representation of the various responses of cultivars to crop management systems using more or less fertiliser and pesticide (Loyce et al. 2002b). Models taking into account the effects of the cultivar on disease development (Le May et al. 2005) or weed competition (Olesen et al. 2004) and the resulting yield loss are also scarce. Concerning the soil structure, the AFISOL model simulates the effects of soil compaction on pea yield, which is one of the main factors explaining the various performances of different pea genotypes (Jeuffroy et al. 2012). Compared to the most frequently used spring genotypes, winter genotypes highly sensitive to photoperiod have recently been bred, that can be sown very early in the autumn, in much better soil conditions than the traditional winter peas, sown later in the autumn, or than spring peas. Including the soil structure effect in the AFISOL model thus gave a good account of the performance of various pea genotypes. Yet most crop models cover a limited range of techniques (sowing, harvest, nitrogen fertilisation and irrigation) and cannot cope with others (soil tillage, crop protection and intercropping), which limits their ability to comprehensively represent the interactions between genotype, environment and cropping system. 
- A small number of assessment criteria: in most cases, yield is the only criterion for evaluating the progress due to a genetic trait. Some studies concern crop quality (e.g. Piper and Boote 1993) but they rarely account for genotype-environment interaction. One exception is given by Barbottin et al. (2006), showing the value of using the crop model Azodyn to support wheat cultivar choice both for yield and grain protein content.

- The hypothesis of independent genetic traits: simulations are generally managed by combining various model parameters, representing genotypic traits considered as independent, without taking into account possible correlations between them (Makowski et al. 2006a). This is often justified by the limited knowledge of the links existing between the traits, and also by the difficulty in representing these links through mathematical relationships in the simulations, even when a link between two traits is known. Thus, Boote et al. (2003) mentioned inverse relationships between leaf thickness and leaf area index (LAI), limiting the value of breeding cultivars with thick leaves: the increase in leaf photosynthesis associated with the increase in leaf thickness is offset by the reduction in intercepted radiation, linked to the decrease in LAI, leading to a stability of yield. Genetic correlations between traits may thus hamper the creation of an ideotype (Yin et al. 2003) or slow progress in breeding efforts as in barley (Jackson et al. 1996). Knowledge of the links between genetic parameters and yield is thus necessary for a successful breeding program (Yin et al. 2003; Jackson et al. 1996).

\subsubsection{Use of cropping system models to simulate the effects of cultivar traits on medium- and long-term ecological impacts}

The evaluation of a genotypic trait or a cultivar type has also been applied, although less frequently in the literature, on the environmental impacts of agriculture (e.g. on water use, biodiversity or soil structure). Quantifying these impacts requires spatial and multi-year processes to be represented on a scale larger than the field and over a period longer than one crop cycle. Leenhardt et al. (2004) simulated the consequences of using various maize cultivars (varying in their earliness) on the water requirement on a regional scale, using a spatial representation of the crop model MODERATO. With the spatially explicit model of gene flow GeneSysrape, Fargue et al. $(2005,2006)$ simulated the consequences of genotypic characters involved in competition (plant height) or in reproduction biology (male sterility, cleistogamy) on the gene flow between fields and on the multi-year evolution of the genetic structure of the volunteer populations in a landscape. Thus they analysed the relative efficiency of various breeding strategies for limiting the risks of genetic contamination of harvests and for optimising the co-existence of various crops within a given crop species in an agricultural landscape. Until now, the effect of cultivars on biodiversity has seldom been analysed, as few models link agronomic and ecological processes on the landscape scale.

2.2 The use of agronomic models for analysing multi-environment variety trials

Cultivars are usually tested in multi-environment trials. The analysis of the data obtained from these networks is often based on the use of statistical models which break down the phenotypic effects into genotype, environment and genotype-environment interaction components but also analyse this interaction effect (Brancourt-Hulmel et al. 1997; Lecomte et al. 2010). In the literature, the use of crop models for analysing data from multi-environment trials has three main goals: (1) a better characterisation of the environments for a possible change in the configuration of the networks, (2) the enrichment of the genotype-environment interaction decomposition by diagnosing limiting factors for probe genotypes, (3) the carrying out of virtual experiments or the adjustment of experimental results (e.g. for earliness, plant density).

\subsubsection{Characterisation and typology of the field environments over an experimental network}

Crop models can help in characterising the environmental conditions encountered in the cultivar trials by probe genotypes or even by each cultivar. According to Chapman et al. (2002), people involved in cultivar assessment could find four advantages from model simulations:

- A better knowledge and typology of the site-specific field environments

- An evaluation of the relevance of the site sampling: do the trial network give a good and unbiased representation of the target population of environments?

- Help to calculate the corrections to apply to take account of bias in environment sampling

- Help to analyse the results of a given trial in a characterised environment

Different studies show that crop models are very useful to characterise the field environments in METs. By their capacity to simulate the evolution of varying soil resources (usually water and nitrogen) and plant growth and nutrient status, which are difficult to measure continuously, they can identify the timing and intensity of water stress or nitrogen deficiency, which are important variables for explaining the various 
responses of genotypes. Chapman et al. (2000), for example, distinguished three types of environment, varying in the intensity and duration of water shortage experienced by sorghum. Based on crop simulations and a breeding model, they showed that a weighted use of these environments to define an experimental network succeeded in selecting suitable genotypes more efficiently than without choosing the environments. A similar approach was carried out by Chenu et al. (2011) on wheat in Australia: using the APSIM model on 100 years of historical weather data, the authors showed that the drought pattern types varied greatly across regions, years and crop management systems. Barbottin et al. (2005) showed that the genotypic variability of nitrogen remobilisation varied greatly according to the limiting factors observed in the environments of the experiments.

Banziger et al. (2006) stated that it is better, although not common, to choose breeding environments similar to the target ones. For example, to minimise experimental error, phenotyping trials are often sown on deep uniform soils, often more fertile than those encountered on commercial farms. In France, no wheat trial for cultivar assessment is grown after a wheat crop, due to the high risk of take-all disease, although $30 \%$ of the wheat crops in the South Paris basin follow wheat. The characterisation of the environments in the cultivar trials could allow to optimise the networks, either by omitting inappropriate environments or by searching for specific environments not yet represented in the networks, or by modifying the proportion of each type of environment in the final analysis according to their relative contribution to the target population of environments (Lecomte 2005).

Crop models could be involved for diagnosing the intensity of stresses experienced by each genotype in each experiment of a cultivar-trial network. For example, by using a crop model Casadebaig et al. (2011) evaluated the number of water stress days in each of the three growing periods (vegetative, flowering and maturation), for five cultivars grown in four different soil/environments (Fig. 3). The model discriminated the environments fairly well; some were characterised by low stress during vegetative and maturation periods, while others had high stress levels throughout the season. The simulations indicated that cultivars suffered differently from water stress in each environment. Simulated genotypic values of water stress days could explain $42 \%$ of
Fig. 3 Use of a sunflower crop model to diagnose water stress over three periods in the cropping season. The figure presents the number of water stress days ( $y$-axis) simulated for five genotypes ( $x$-axis) in three environments (horizontally) and three periods of the crop cycle (vertically). Grain yield $(G Y, \mathrm{t} /$ ha) and leaf area index ( $L A I)$ measured on field trials are indicated for reference, for each environment. Water stress days were computed as the cumulative number of days when the plant transpiration was significantly affected in the crop model (ratio actual/maximal evapotranspiration lower than 0.6). Simulation allowed identification of water stress patterns (colored headings) based on the position and intensity of the simulated indicator. These stress patterns were consistent with observed crop variables (LAI, gain yield). Simulated indicators can later be used to characterise environments and to improve genotype assessment in multienvironment trials analysis

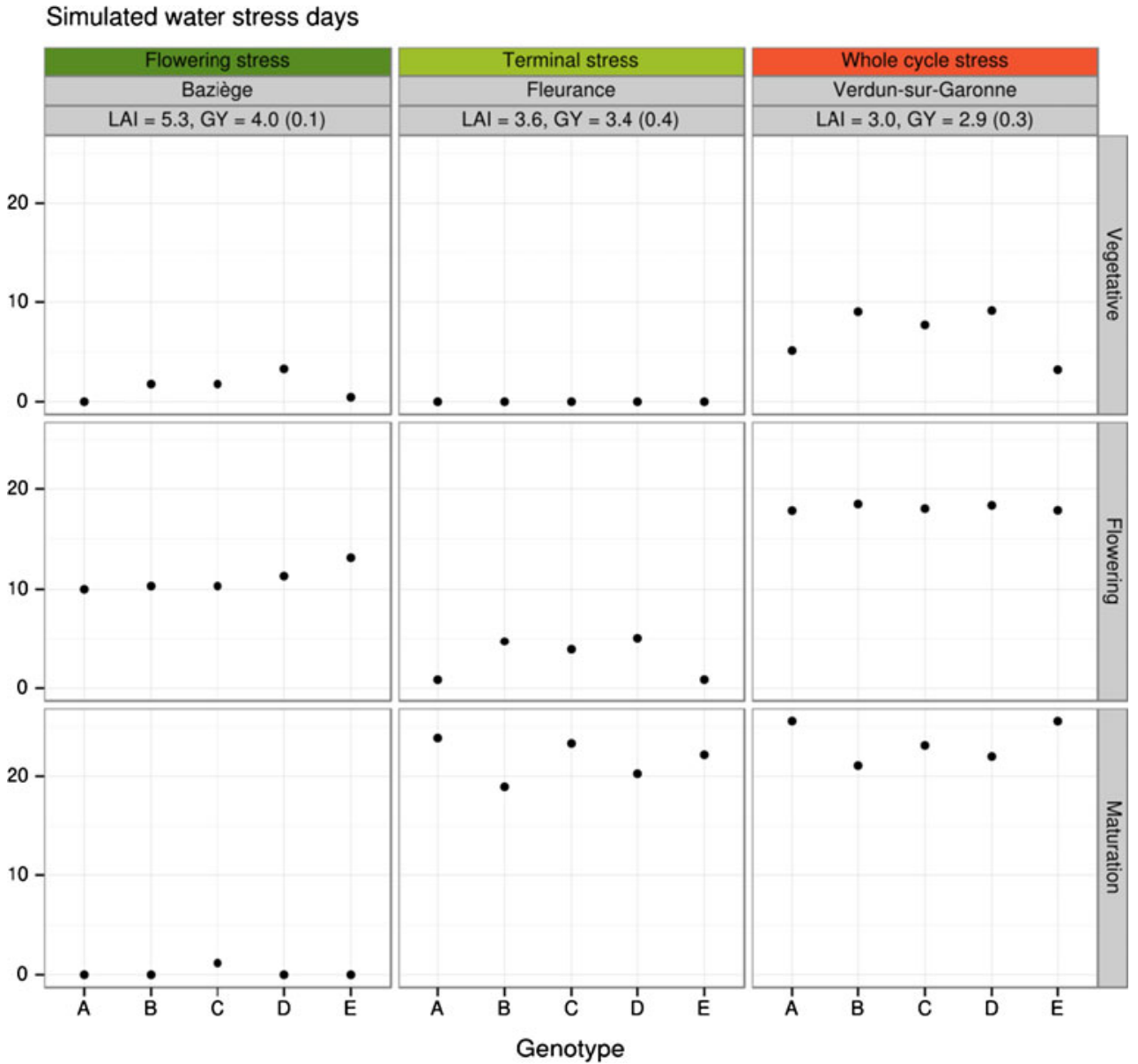


total observed yield variance: a stress in the vegetative period favoured high yields, whereas stress during flowering or especially during maturity was detrimental.

However, there are several main limitations to the use of crop models for characterising environments. Firstly, some data for this characterisation are not always available at field level (e.g. weather data or soil depth) or may require timeconsuming protocols (nutrient and water status of the crop). Secondly, the field experimenters are not concerned directly by the use of the collected information (Lecomte et al. 2010), and are thus reluctant to spend time acquiring it. Thirdly, time is required to analyse these data and use the results for the following experiment, which is not always available in the very short period between two crop cycles (Lecomte et al. 2010). Finally, as mentioned above, models generally do not take account of the wide range of limiting factors observed in farmers' fields, which results in an incomplete environmental characterisation.

\subsubsection{Breaking down the genotype-environment interaction}

Statistical models have been developed extensively in the past to gather the information coming from trials comparing genotypes, separating the effects of the genotype, the environment and the genotype-environment interaction (Brancourt-Hulmel et al. 1997). In order to identify the factors explaining the variability of genotype responses in various environments, the genotype-environment interaction can be split into environmental covariates (BrancourtHulmel et al. 2000; Foucteau et al. 2001) and genotypic covariates (Voltas et al. 1999a, b). As the measurement of environmental variables is scarce in cultivar trials, it has been shown that the use of crop simulation models to generate covariates could be efficient for analysing differential responses of genotypes to environmental factors (Saulescu and Kronstad 1995; Chapman 2008; Asseng and Turner 2007).

\subsubsection{Carrying out virtual experiments}

Models facilitate the enlargement of the range of conditions in which the response of the cultivars can be tested. Limited by cost constraints, the experimental networks generally do not allow the exploration of all the variability encountered in farmers' fields. New cultivars are generally tested for relatively few years before their release to farmers. The large number of weather patterns that models can explore should allow the user to better identify the situations in which a varietal type is promising or should be avoided. This method allows virtual experiments to be carried out and the contributions of genotype, environment and genotype-environment interaction to the total variance of the analysed variable to be calculated (Casadebaig et al. 2011). Using a crop model, Hammer et al. (1996) evaluated the contributions of the phenology, the stay-green character and the transpiration efficiency at 4,75 and $15 \%$ respectively of the total variation in the sorghum yield, which was close to the experimental results. They also showed that most of the genotype-environment interaction was explained by phenology (crop lifespan). For the grain protein content of winter wheat, Makowski et al. (2006b) showed that most of the variance is explained by the efficiency of nitrogen remobilisation to the grain, the shoot-root ratio for nitrogen partitioning, and the maximum yield, these three parameters differing between winter wheat genotypes.

Moreover, models could be useful to correct the observed results from the experimental bias. Indeed, in cultivar trials, crop techniques such as nitrogen fertilisation or fungicide treatments are generally applied on a particular date, and not at the optimal stage for each cultivar, thus leading to possible bias. For example, the response of the wheat grain protein content to the last $\mathrm{N}$ fertiliser application depends on the delay between this application and the flowering date. In a cultivar trial, as fertilisation is applied at the same date for all cultivars, this delay may differ considerably (by as much as 3 weeks) between genotypes, resulting in cultivar differences in grain protein content which are attributable to the management and not directly due to intrinsic genetic traits. Similarly, choosing a single sowing date (because of experimental constraints) to compare varieties with different optimal sowing dates may be unfair to some cultivars. In some variety trials, plant density also may differ slightly between cultivars under comparison.

By virtually applying the crop techniques at various dates according to phenology (for instance by triggering decision rules) or by normalising plant population, the model could help to quantify the gap between the observed results and the results that should be reached in optimal conditions. To our knowledge, there is no published example of such correction methods used in cultivar assessment.

2.3 The use of agronomic models to support the choice of the cultivar according to the crop management and the environment

Lecomte et al. (2010) showed that most people involved in cultivar evaluation (marketing sections of breeding firms, seed multipliers, technical advisors, agrochemical salesmen etc.) aim, through their cultivar-trial networks, to define the suitability of new cultivars to various production areas, soil types and crop management techniques (sowing date and density, nitrogen fertilisation, crop protection strategies and irrigation). This requires the analysis and prediction of the interactions between genotype, environment and cropping system, namely to understand how crop management interacts with cultivars in various soil-weather conditions. The 
crop techniques most often considered in crop models are the sowing date, density, irrigation and nitrogen management which are consistent with the abiotic processes generally considered by the models.

\subsubsection{Choice of the cultivar for given conditions of soil and weather}

Numerous studies based on simulations aim at defining the best type of cultivar (rarely the best actual cultivar) for a given soil and climate. Most studies concern arid or semiarid zones characterised by very variable amounts and distribution of rainfall, for which simulation is recommended because experiments cannot cover the whole range of weather variability (e.g. Stapper and Harris 1989; Singels and de Jager 1991; Muchow et al. 1994; Goyne et al. 1996; Debaeke 2004). The method is then to calculate, with crop models, the cumulative yield probability associated with each cultivar for a given set of weather patterns. Batchelor et al. (2003) analysed, for example, the value of sowing several soybean cultivars in the same field faced with soil and weather variability. Jeuffroy et al. (2012) combined three models to analyse the value of different types of pea cultivar: spring cultivars (sown in February-March), winter cultivars (sown in mid-November) and new winter cultivars highly sensitive to photoperiod (sown in October). A crop model simulated pea yield depending on the soil structure, the sowing date and the weather. A model of the evolution of soil structure simulated the risks of compacted soil, depending on sowing date, the type of soil tillage and the weather. Finally, a model of work organisation on the farm simulated the sowing dates for pea crops according to weather conditions and to farmers' priorities between field operations. The results showed that the new winter cultivars had more stable yields, and this advantage was greater when considering the constraints in real farms than in factorial experiments, where a delay in the sowing date, and thus soil compaction, were less frequent.

\subsubsection{Choice of the combination of cultivar and crop management system}

The use of crop models to choose the cultivar and the crop management system together is still rare. The genotypic characteristics that are the most frequently included in crop models concern crop phenology, which explains much of the yield variability when water is the main factor limiting yield. This may explain why models have mostly been used in Australia to identify the best choice of cultivar and crop management (Hammer et al. 1996; Chapman et al. 2002). For the same reasons, there have been several studies on crop management for sorghum in various water availability situations (Baumhardt and Howell 2006; Debaeke and Nolot 2006). In western European conditions, yield is more often limited by diseases, which are rarely simulated by models. The use of crop models to identify the best cultivar-crop management choice is thus less common. Yet an example is given in the study of Loyce et al. (2002b) who suggest using the BETHA model (Loyce et al. 2002a) to choose the variety, plant density, $\mathrm{N}$ fertilisation and pest management for bioethanol wheat production.

Finally, while the use of crop models to help breeding by integrating information on genetic determinism of morphophysiological traits and by coupling them with quantitative genetic models is rapidly developing (Chapman et al. 2003; Hoogenboom et al. 2004; Messina et al. 2006), there are still few examples where crop models are used within decision support systems for guiding cultivar choice (Debaeke et al. 2011).

\section{A method to take into account the cultivar in crop models}

The use of crop models to analyse and predict the performance of cultivars requires the models to describe the contrasting behaviour of varieties in various environments. Taking the cultivar into account explicitly in models is generally achieved by varying certain model parameters, possibly after adaptation of the model structure. This requires three main methodological questions to be answered:

- What characteristics must the crop model have to give a good prediction of the interactions between genotype, environment and cropping system?

- How does one identify and estimate the cultivar parameters?

- How should one evaluate the model for such uses?

3.1 Which models give a good account of the interaction between genotype, environment and cropping system?

\subsubsection{Complexity level of the models}

The analysis and prediction of the interactions between genotype, environment and cropping system can be based on various models: from mechanistic models describing some fine processes at the plant level in physiological modelling approaches (Yin and van Laar 2005; Yin and Struik 2010) to more empirical models involving a wide range of environmental and agronomic conditions. The question of the required level of complexity in a model to give a good prediction of the differences between genotypes is still debated by modellers:

- Some consider that it is necessary to describe in detail the elementary processes for which the control by genes can be simulated (e.g. Yin et al. 2000; Hoogenboom et al. 2004). However, in order to give a good account 
of the whole crop cycle in its environment, this would require the description of a very large number of relationships between genes and phenotypes to be included in these models, and relationships simulating the effect of the environment on the multiple gene expressions.

- Others argue that simpler models are needed, because they are more consistent with the breeders' activity and thus can be more easily used, and are based on more robust relationships (Shorter et al. 1991; Sinclair and Muchow 2001; Zhang et al. 2006). Genotypic differences can sometimes be represented with basic models. For example for sorghum, the cultivar differences in phenology and in radiation use efficiency are sufficient to differentiate old and modern cultivars in situations where water is the main limiting factor (Sinclair and Muchow 2001).

The two methods are not mutually exclusive: Shorter et al. (1991) suggest beginning with a simple model and elaborating it if necessary by introducing new traits. Yet, the method for justifying the elaboration of the model was not suggested. We assume that models for breeding and models for defining the conditions of use of the cultivars should be different. To favour the link between model and breeding, the first ones could be more efficient if they involve relationships between parameters and genes or groups of genes, while representing the effects of crop techniques on the whole crop cycle (e.g. in GeneSys where the gene for cleistogamy is represented by two parameters, the rate of pollen release and the autogamy rate, Fargue et al. 2006). To define the conditions of use of cultivars, the model should include a simple method for quickly parameterising each new cultivar.

In order to estimate the model parameters for the large number of new varieties registered each year and be able to predict their performance in the target population of environments, it is necessary to develop quick, easy and accurate phenotyping methods, as described by Barbottin (2004) for wheat (Table 1) and by Debaeke et al. (2011) for sunflower. These methods are based on the measurement of a limited number of traits (in field or greenhouse conditions) which are directly used as model parameters. In order to favour the link between high throughput phenotyping and model parameterisation, Jeuffroy et al. (2006) affirm the need to use formalisms, including easily measured parameters representing characters on which the cultivar selection can be based.

Whatever the model's complexity, the interactions between genotypic traits are scarcely considered in present models. For example, Chapman et al. (2003), unlike Hammer et al. (1996), do not consider the relationship between the transpiration efficiency and the crop radiation use efficiency. The physiologically based models that incorporate the effect of genes or gene groups do not adequately take into account the interactions between physiological characters, because their effects on the parameter values are additive (Hoogenboom et al. 1997; Hunt et al. 2003; White and Hoogenboom 1996). While these models seem appropriate to address genotype-phenotype relationships (Yin and van Laar 2005; Yin and Struik 2010), their use raises three problems. First their genotypic-dependent parameters should be easily estimated and should not vary with environmental conditions, which is not always the case (Reymond et al. 2003). Second, these models generally do not take into account the complex range of environmental conditions encountered in a farmer's field, as they focus on a small number of limiting factors (Reymond et al. 2003 for instance), which limits the prediction of the interactions between genotype, environment and cropping system. Finally, their complexity often limits these models to a small part of the agrosystem

Table 1 Cultivar parameters of the Azodyn model, their values for ten cultivars and the method for their estimation

\begin{tabular}{|c|c|c|c|}
\hline $\begin{array}{l}\text { Name of } \\
\text { the } \\
\text { parameter }\end{array}$ & Signification of the parameter in the model & $\begin{array}{l}\text { Range of the parameter } \\
\text { values for the studied } \\
\text { genotypes }\end{array}$ & Method for the estimation of the parameter values \\
\hline YLDx & Maximum yield & $8.61-11.37 \mathrm{Mg} / \mathrm{ha}$ & $\begin{array}{l}\text { Maximum yield measured on a large database from a range } \\
\text { of pedo-climatic conditions }\end{array}$ \\
\hline TGWx & Maximum thousand grain weight & $\begin{array}{l}87.49-136.08 \mathrm{~g} / 1,000 \\
\text { grains }\end{array}$ & $\begin{array}{l}\text { Estimation of the parameters of the plateau-plus-linear } \\
\text { boundary curve linking thousand grain weights and grain } \\
\text { number per square meter, on a large database (Makowski } \\
\text { et al. 2007) }\end{array}$ \\
\hline alphaGN & $\begin{array}{l}\text { Ratio of the maximum grain number allowing } \\
\text { to reach TGWx between the cultivar and a } \\
\text { reference cultivar (Soissons) }\end{array}$ & $0.62-1.13$ & $\begin{array}{l}\text { Ratio of the grain number thresholds, between a cultivar and } \\
\text { the reference Soissons, between the plateau and the linear } \\
\text { parts of the plateau-plus-linear boundary curve linking } \\
\text { thousand grain weights and grain number per square } \\
\text { meter, on a large database (Makowski et al. 2007) }\end{array}$ \\
\hline
\end{tabular}


(an organ, as in Reymond et al. 2003) and do not allow linking the gene effect with the cropping systems, which limits their use for two of the three aims developed in part 2. The processes described in the model are more important than the complexity level of the model in its capacity to predict the interactions between genotype, environment and cropping system.

\subsubsection{Processes involved in the model}

In the previous examples, various models were concerned: dynamic crop models with a daily time step (in most models), physiologically based models, cropping system models with various time steps, models at the scale of the plot or the landscape, sometimes spatially explicit. The model chosen depends heavily on the processes required in the simulation to give a correct representation of the interactions between genotype, environment and cropping system. Therefore the formalism should follow the hierarchy of limiting factors occurring in the study area and the importance of genotypic susceptibility to these factors. For example, a model used to simulate the varietal performances in low-input conditions needs to represent the varietal response to low plant densities, nitrogen deficiencies, water stress, weed competition, disease pressure etc. The BETHA wheat model (Loyce et al. 2002a) was built to design new crop management systems for various levels of inputs and various production goals. It does not include a weed module, as weed control should be planned at the rotation level, but it considers the application of insecticides, growth regulators and fungicides, which is rarely the case in crop models. The disease module is based on a simple formalism (a combination of linear static models fitted to field data) including the combined effects of cropping systems and varietal resistance on the yield loss due to disease (Zhang et al. 2007). Finally, all of the BETHA cultivar parameters are easily available, mainly from the usual disease scoring done by the French registration organisation (GEVES), which is to be expected from a model aimed at designing crop management plans and cultivar choice.

In other cases, the processes required in the simulation lead to more sophisticated formalisms. For example in sunflower, genotypes differ significantly in their leaf area growth and senescence pattern (number of leaves, vertical distribution of leaf area, total plant leaf area etc.) but also in the sensitivity of leaf expansion to water stress. For a given variety, there is a wide range of leaf area index (from 2 to 5), depending on the relative timing of leaf growth and water stress, with consequences for canopy radiation interception, water use and disease development. In a model aimed at evaluating the escape and avoidance strategies for water stress (crop management systems or cultivars), it was more efficient to represent leaf growth at the leaf scale rather than at the plant scale, in order to capture the dynamic effects of water stress without increasing the number of parameters (Casadebaig et al. 2011).

\subsection{How to identify and estimate the cultivar parameters?}

\subsubsection{Which parameters vary among genotypes?}

While the use of genotypic traits in models is common, the criteria whereby a parameter is considered as genotypic are seldom described in the literature. However, crop models generally include a large number of parameters (up to 300 in some cases) and it would be inappropriate and illusory to try to adapt all of them to the range of genotypes studied.

Boote et al. (2003) proposed to analyse the sensitivity of the model to its parameters, in order to identify those to modify as they have a clear effect on the outputs. In dynamic crop models, which usually contain many parameters, this analysis can be achieved only after selecting a small number of those for which genotypic variability has already been observed or assumed, even if not yet assessed. This method has been used for the adaptation of the Azodyn crop model to various wheat cultivars (Barbottin 2004; Makowski et al. 2006b) and to build the SUNFLO model for sunflower (Casadebaig et al. 2011). The model sensitivity to parameters appears highly dependent on the output considered and on the growing conditions assumed for the simulations. Moreover, the results of the sensitivity analysis are closely linked with the range of each parameter, either observed or assumed. For example, the parameter representing $\mathrm{N}$ remobilisation from vegetative parts to the grain is assumed to vary among genotypes (Cox et al. 1986), and was shown to have a big effect on the grain protein content (Makowski et al. 2006b). Yet no significant variation was observed among varieties in disease-free trials (Barbottin et al. 2005). Because the sensitivity analysis on one parameter depends on the weight of the other parameters in the model outputs, the large effect of the remobilisation parameter, treated as a variable in the sensitivity analysis, could have hidden the effect of other parameters.

Practically, the selection between the parameters varying with genotypes and those whose value is stable takes into account (1) the existing knowledge on the effect of the traits represented by the parameters on crop behaviour, (2) the significant effect of the parameters on the variables simulated by the model, and (3) the expected use of the model. In most cases, the chosen parameters are included in the modules simulating (1) crop leaf area and growth (Asseng et al. 2003; Agüera et al. 1997; Colson et al. 1995), (2) crop development (Brisson et al. 2002; Hammer et al. 1982; Villalobos et al. 1996; Boote et al. 2001) and (3) yield formation, with the values of its components (Boote et al. 2003; Bannayan et al. 2003; Travasso and Magrin 1998; Barbottin et al. 2006). More rarely, parameters linked with 
other physiological processes have been analysed, such as the evapotranspiration efficiency, the osmotic adjustment, the crop's ability to maintain a high photosynthetic activity during grain filling, called the "stay green character" (Chapman et al. 2003), or the growth vigour during the young stages (Agüera et al. 1997). Some models also include the effect of genotypic characters on the interactions between genotype and pest (through the resistance scores, Zhang et al. 2006), on the lodging risk (Yin et al. 2000) or on genotypic characteristics with an effect on the risks of genetic contamination such as the morphology of reproductive organs (Fargue et al. 2006). Ease of measurement of these parameters in breeding or advisory trials may be necessary to guarantee their use (Brisson et al. 2002; Barbottin et al. 2006).

\subsubsection{Estimation of the genotype-dependent parameters}

Two main methods are found in the literature to estimate the parameter values for a given range of genotypes in the case of deterministic models: (1) the optimisation of the parameters by fitting one or several variables simulated by the model to their observed values, or (2) the direct measurement of the parameter values independently from the model.

Estimating parameters by minimising errors in model outputs The estimation of parameters by optimising model outputs aims at identifying the parameter values that minimise the differences between the simulated and observed values of outputs (Irmak et al. 2000). For example, Mavromatis et al. (2001) proposed to estimate the values of eight genotypic parameters from information collected in soybean trials on flowering and maturity dates, yield and mean weight per seed. Mavromatis et al. (2002) applied this method in two regions with the same genotypes, which resulted in stable values for some parameters (e.g. the critical daylength sensitivity), but led to unstable values of others (the duration of the grainfilling period and the photosynthetic efficiency differed between sites for a given genotype). Wallach et al. (2001) proposed to use a method combining (1) one criterion for selecting the parameters to estimate (maximum likelihood), and (2) one criterion for the estimation of the parameter value by fitting simulated data to observed data (mean squared error of prediction). The results show that, according to the number of parameters estimated simultaneously, the parameter values can be very different, indicating compensation between them (Jeuffroy et al. 2006).

The biological meaning of the parameters estimated by fitting outputs is thus questionable, as the values are directly dependent on the model structure and the values of the other parameters. For a given parameter, the variability of fitted values between environments (Mavromatis et al. 2002) indicates that some processes are not taken into account in the model, whereas they have an effect on the variables on which the optimisation is based. The parameter values can thus compensate for errors in the model equations. One method to limit this problem is to optimise intermediate variables (and not just outputs), closer in the model structure to the parameters to be evaluated, providing that these variables can be measured. Moreover, the estimated values depend strongly on the data available for calibration. For users who only have 1 year of experimental data and demand the best possible initial guess for the coefficients of their specific cultivar, Bannayan and Hoogenboom (2009) developed a pattern recognition approach for maize, based on similarity measures, to estimate cultivar coefficients from a base of hypothetical cultivar features built with a crop simulation model.

Estimating parameters independently from the model The other way used in the literature is based on the direct measurement of parameters. In order to use this method, the model formalism needs to be adapted. The ease of parameter estimation should be taken into account early in the model's design. The parameters estimated from direct measurement by Liu (1989) or Barbottin (2004) are those describing the phenological stages (duration of the periods between sowing and flowering and between flowering and maturity) and yield components (potential grain number and mean weight per grain). In the sunflower model developed by Casadebaig et al. (2011), the genotype was described by 12 parameters measured in evaluation trials (phenology, architecture, biomass and oil allocation) or in the greenhouse (expansion and transpiration response to water stress) using defined environments in order to control the environment effects.

This method often requires specific trials and measurements, sometimes difficult and expensive to apply to a large number of genotypes (Reymond 2001; Casadebaig et al. 2008). In some cases it is possible to estimate parameters via indirect variables regularly measured in the trials (for example, in sunflower, the grain moisture content at harvest can be used to estimate the time from flowering to maturity). As parameters sometimes vary according to the trial conditions, it is often possible to estimate relative values calculated according to reference genotypes (for example, the relative potential yield used in BETHA, Loyce et al. 2002a), which are often more stable among environments.

Finally, the estimation of parameter values should also take into account the measurement errors. For example, the estimation of potential values for yield or yield components, often used in crop models, should be based on rigorous statistical methods (Brancourt-Hulmel et al. 1999; Makowski et al. 2007).

Whatever the method used for parameter estimation, the choice of identifying genotypic parameters in crop models should result from a cost-benefit analysis comparing the 
gain in model predictive quality and the effort in parameter measurement or database collection, which is rarely mentioned in the literature. It makes sense to pool cultivars with similar characteristics into classes, as proposed by Zhang et al. (2006) and Loyce et al. (2008) on disease resistance and lodging scores. Such a classification should facilitate the quick identification of the group to which a new variety belongs and hence the prediction of its response in various environments. However, concerning the response to abiotic stresses (water, nitrogen and temperature), the characterisation of genotypic differences is more difficult to achieve in regular field trials as likely environmental conditions (e.g. soil water or nutrient content) are difficult to record at variety level because of intra-specific differences in soil resource use with time.

\subsection{Evaluation of the model quality for decision support in cultivar and crop management choices}

Besides the classical evaluation of the errors of prediction of crop models, it appears essential to assess their ability to make good decisions, i.e. to achieve the goals of the potential users. For models adapted to cultivars, three main uses have been partly described (1) definition of breeding targets, (2) agronomic diagnosis in cultivar trials and (3) choice of the best use of cultivars. As Lecomte et al. (2010) showed, the information required on cultivars differs according to the stakeholder considered (breeder, farmer, advisor etc.) and the stage in the cultivar's development (breeding, preregistration and post-registration). Thus we propose two steps to evaluate the decisional quality of models: (1) the identification of the questions which the model should answer from the targeted uses, (2) the identification of the evaluation criteria showing whether the model can address these questions. These criteria can be calculated by comparing the simulated results with the experimental data (independently of those used for model parameterisation) or with the results of another model. Not much research has been carried out on this question. Two examples, corresponding to different uses of the model, are given below.

\subsubsection{Predicting cultivar performance in various environments with the same management}

The first example concerns the Azodyn crop model (Jeuffroy et al. 2000; Barbottin 2004), simulating the effect of cultivar and wheat crop management (nitrogen fertilisation, stubble management, sowing date and density) on yield, grain protein content and the amount of mineral nitrogen in the soil at harvest, for various soil/weather environments. The model was evaluated on its ability to identify wheat ideotypes more stable for yield and grain protein content (Barbottin et al. 2006). An analysis of the users' requirements (breeders and other stakeholders) showed that cultivar behaviour should be analysed through the genotype's stability of performance in various environments (use 1), and also through its ranking for yield and grain protein content in various growing conditions (use 2). Thus, two criteria were proposed to evaluate the decisional quality of the model: (1) the environmental variance used to forecast the stability level of a genotype (use 1), as defined by Becker and Leon (1988), and (2) the result of Spearman's ranking test, based on a correlation coefficient between observed and simulated ranking, that aims at evaluating the model's ability to rank genotypes on their performance in a given environment (use 2). The results indicate a tendency of the Azodyn model to under-estimate the values of environmental variance (use 1), but with a good prediction of the relative stability of genotypes (use 2). To test the accuracy of the model for the genotype ranking, the results from Azodyn were compared to experimental data and to the cultivar yield and average grain protein (Barbottin et al. 2006). This choice was based on the activities of the users, who generally compare genotypes on the average ranking on all environments (Lecomte et al. 2010).

\subsubsection{Predicting cultivar performances in various crop management systems}

The second example concerns the BETHA model (Loyce et al. 2002a), simulating the combined effects of a crop management plan and cultivar on yield, grain protein content and gross margin. The decisional quality of the BETHA model was assessed through the ability of the model to identify, for a given price-environment situation, the best cultivar-crop management combination and, for a given cultivar, the best crop management (Zhang 2005). This was done by comparing the simulated and observed rankings with the Spearman rank test on a multi-site and multi-year trial network (19 trials), where 12 cultivar-crop management pairs were tested. The model gives a good prediction of the ranking for yield in all 19 trials, but only in six trials for grain protein content, nine trials for gross margin with a high wheat price and 11 trials for gross margin with a low wheat price (Zhang 2005). The capacity of the model to identify the best crop management plan for a given cultivar was assessed by comparing those giving most often the best gross margin in observed and in simulated conditions for a given cultivar (Fig. 4).

\subsubsection{Value of the evaluation of decisional quality}

As shown by the two examples, the usual evaluation of predictive quality of a model is not the best way for assessing its decisional quality in decision support. Houlès et al. (2004) 


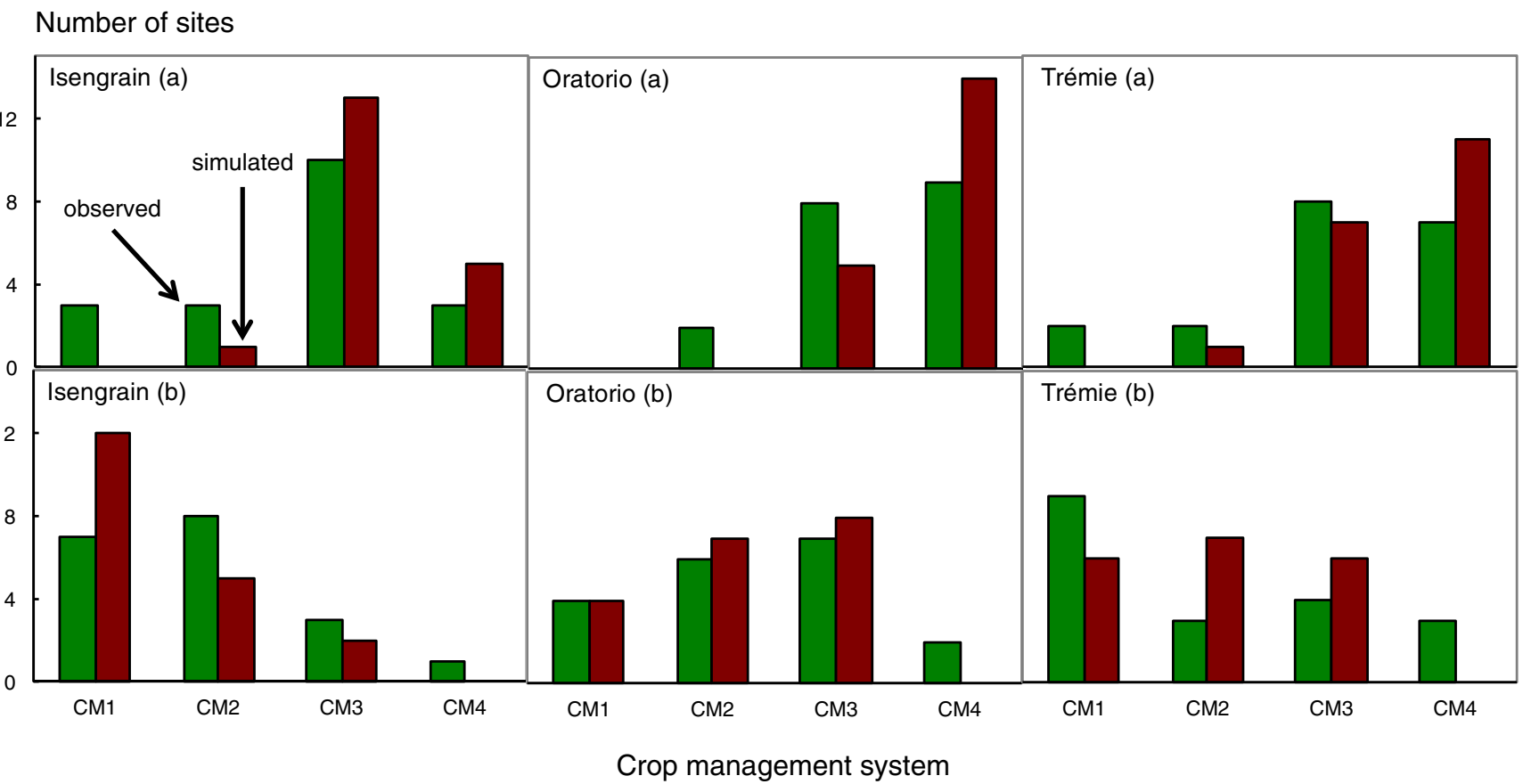

Fig. 4 Comparison of the number of sites (observed and simulated by the BETHA model) in which the cultivar-crop management plan pair resulted in the highest value of gross margin for two winter wheat grain prices $\left(\mathbf{a}=76 € \mathrm{t}^{-1}\right.$ and $\left.\mathbf{b}=137 € \mathrm{t}^{-1}\right)$ : three cultivars (Isengrain, Oratorio, Trémie) and four crop management plans (CM1 = high sowing density, three $\mathrm{N}$ applications, non-limiting $\mathrm{N}$ rate, three fungicides and two growth regulators; $\mathrm{CM} 2=$ high sowing density, three $\mathrm{N}$ applications, $\mathrm{N}$ rate calculated for a possible yield target, two fungicides and one growth regulator; $\mathrm{CM} 3$ = low sowing density, two $\mathrm{N}$ applications, $\mathrm{N}$

mentioned that crop models have generally a low predictive quality for yield (the root mean square error varies for wheat between 0.4 and $1.4 \mathrm{t} \mathrm{ha}^{-1}$ in the literature) and for grain protein content (root mean square error ranging between 1.5 and $1.7 \%$ ). But as regards the model development and its use by advisors or stakeholders, it is generally more interesting to demonstrate that the model can help in ranking cultivars, in spite of its low predictive quality for yield or grain composition. Estimating all cultivar parameters in the model should be unnecessary if genotype ranking is well predicted with only a small number of them. Very few studies describe assessment of the ranking of genotypes: Mavromatis et al. (2001) compared the mean genotype ranking between the CROPGRO-soybean model and experimental data. However, ranking varieties is not always the main objective, and a previous study of the stakeholders' requirements in the way they use the model may be necessary. This could be supported by design ergonomists (Lecomte et al. 2010). Moreover, it is often difficult to identify the assessment criteria most suited to the target use, while for the assessment of the predictive quality, the criterion MSEP is now widely used (Wallach and Goffinet 1987, 1989). rate lower than the recommended in $\mathrm{CM} 2$, one fungicide, no growth regulator; and $\mathrm{CM} 4$ = low sowing density, two $\mathrm{N}$ applications, lower $\mathrm{N}$ rate than $\mathrm{CM} 3$, no fungicide and no growth regulator). This comparison allows us to assess the capacity of the BETHA model to identify the best CMP for a given cultivar. In half of the cases (three upon six), the BETHA model identified the best CMP (as observed in the trials). It also identified the two CMP reaching the highest gross margin in five cases upon six

\section{Conclusion}

The use of agronomic models for analysing and predicting the genotypic response in various cropping systems and environments is increasing in the literature, although they are not yet widely used by plant breeders and their associates. For these stakeholders, experimentation (requiring considerable expertise for data interpretation) is still the main way of testing cultivars. As has been frequently shown in the literature, models can be a complementary tool to:

- Analyse the experimental field data, through additional agronomic diagnosis

- Extrapolate the experimental results, by simulating situations not encountered in the experiments because of limited time, shortage of resources or because certain phenomena did not occur during the years of the experiments. For example disease pressure may have been low, making it difficult to assess cultivar resistance to diseases. This is often the case for the models predicting the interactions between genotype, environment and cropping system 
- Define the size and the nature of the experimental network, by suggesting reduction or enlargement of the range of genotypes and soil-weather combinations to explore

Thus, in the method described in part 3 the experimentation and the modelling approach are strongly linked: the experiments are useful to estimate the cultivar parameters to take into account in the model and to evaluate the model, and the model is used to extrapolate the results over environmental and management ranges not encountered in the experiments.

However, the use of models will always have limitations: the evaluation of a variety with a model does not take into account its insertion in the cropping system and the conclusions may be biased or partial. For example, the cultivars of oilseed rape which are adapted to early sowing (favouring rapid soil $\mathrm{N}$ uptake and thus low nitrate losses through leaching) need to be resistant to phoma stem canker because a high crop nitrogen status leads to a higher risk of this disease (Aubertot et al. 2004). Varieties intended for organic farming need to be more competitive against weeds as weed competition is the main limiting factor for yield in this system. They should also be adapted to late sowing, necessary to control weeds with the "false seedbed" technique (soil tillage before sowing) (Meynard and Jeuffroy 2002). In these cases, models cannot be used to identify the traits for a given target or given growing conditions to breed for, because they do not simulate all the effects of cropping systems. Moreover, breeding according to criteria suggested by simulations is still questionable: even if useful ranges for the most influential parameters of crop models exist in gene banks, it is not always easy to link these parameters to criteria usable by breeders.

The limitations to the wider use of models in variety breeding and evaluation involve numerous avenues of research. Thus, the inability of models to give a good prediction of cultivar differences, which are sometimes small among varieties from the same breeding generation, could be improved by using methods combining model and experimental data, through data assimilation techniques, as shown by Naud et al. (2007). Moreover, on-going progress in sensitivity analysis methods could benefit the determination of genotype-dependent parameters in models. Few methods are available nowadays to run sensitivity analysis on complex models by taking account of correlations between parameters or by using dynamic variables (Lamboni et al. 2009). When genotype-dependent parameters can be easily recorded by people choosing cultivars, it will be necessary to create a method for building cultivar typology in order to identify those best suited to given environments and crop management systems.

With the dissemination of models among decision-makers in cultivar breeding and assessment, these new tools could supplement the traditional use of experimentation. With this aim, we should involve future model users at the design stage in order to encourage their learning and to consider the future use of the model.

Acknowledgements The authors thank Alan Scaife for the English language revision.

\section{References}

Aggarwal PK, Kropff MJ, Cassman KG, ten Berge HFM (1997) Simulating genotypic strategies for increasing rice yield potential in irrigated, tropical environments. Field Crops Res 51:5-17. doi:10. 1016/S0378-4290(96)01044-1

Agüera F, Villalobos FJ, Orgaz F (1997) Evaluation of sunflower (Heliantus annuus, L.) genotypes differing in early vigour using a simulation model. Eur J Agr 7:109-118. doi:10.1016/S11610301(97)00023-3

Argillier O, Hébert Y, Barrière Y (1994) Statistical analysis and interpretation of line $\mathrm{x}$ environment interaction for biomass yield in maize. Agronomie 14:661-672. doi:10.1051/agro:19941003

Asseng S, Turner NC (2007) Modelling genotype $\times$ environment $\times$ management interactions to improve yield, water use efficiency and grain protein content in wheat. In: Spiertz J H J et al. (eds.) Scale and complexity in plant systems research: gene-plant-crop relations, Springer, pp 93-104

Asseng S, Turner NC, Ray JD, Keating BA (2002) A simulation analysis that predicts the influence of physiological traits on the potential yield of wheat. Eur J Agr 17:123-141. doi:10.1016/ S1161-0301(01)00149-6

Asseng S, Turner NC, Botwright T, Condon AG (2003) Evaluating the impact of a trait for increased specific leaf area on wheat yields using a crop simulation model. Agron J 95:10-19. doi:10.2134/ agronj2003.1000

Aubertot JN, Pinochet X, Doré T (2004) The effects of sowing date and nitrogen availability during vegetative stages on Leptosphaeria maculans development on winter oilseed rape. Crop Prot 23(7):635-645. doi:10.1016/j.cropro.2003.11.015

Bannayan M, Hoogenboom G (2009) Using pattern recognition for estimating cultivar coefficients of a crop simulation model. Field Crops Res 111:290-302. doi:10.1016/j.fcr.2009.01.007

Bannayan M, Crout MJ, Hoogenboom G (2003) Application of the CERES-wheat model for within season prediction of winter wheat yield in the United Kingdom. Agron J 95:114-125. doi:10.2134/ agronj2003.1140

Banziger M, Setimela PS, Hodson D, Vivek B (2006) Breeding for improved abiotic stress tolerance in maize adapted to southern Africa. Agric Water Manag 80:212-224. doi:10.1016/j.agwat. 2005.07.014

Barbottin A (2004) Utilisation d'un modèle de culture pour évaluer le comportement des génotypes: Pertinence de l'utilisation d'Azodyn pour analyser la variabilité du rendement et de la teneur en protéines du blé tendre. Thèse de Doctorat, INA P-G, Paris

Barbottin A, Lecomte C, Bouchard C, Jeuffroy MH (2005) Nitrogen remobilisation during grain filling in wheat: genotypic and environmental effects. Crop Sci 45:1141-1150. doi:10.2135/ cropsci2003.0361

Barbottin A, Le Bail M, Jeuffroy MH (2006) The Azodyn crop model as a decision support tool for choosing cultivars. Agron Sustain Dev 26:107-115. doi:10.1051/agro:2006003 
Baril CP (1992) Factor regression for interpreting genotype-environment interaction in bread wheat trials. Theor Appl Genet 83:1022 1026. doi:10.1007/BF00232967

Batchelor WD, Paz JO, Jones JW (2003) Estimating break-even cost to move from single to multiple soybean variety management within a field. In: Proc. 4th European Conference on Precision Agriculture, Berlin (Germany), 15-19 June 2003, pp 69-74

Baumhardt RL, Howell TA (2006) Seeding practices, cultivar maturity, and irrigation effects on simulated grain sorghum yield. Agron J 98:462-470. doi:10.2134/agronj2005.0156

Becker HC, Leon J (1988) Stability analysis in plant-breeding. Plant Breed 101:1-23. doi:10.1111/j.1439-0523.1988.tb00261.x

Biarnès-Dumoulin V, Denis JB, Lejeune-Hénaut I, Etévé G (1996) Interpreting yield instability in pea using genotypic and environmental covariates. Crop Sci 36:115-120. doi:10.2135/cropsci1996. 0011183X003600010021x

Boote KJ, Jones JW, Pickering NB (1996) potential uses and limitations of crop models. Agron J 88:704-716. doi:10.2134/agronj1996. $00021962008800050005 x$

Boote KJ, Kropff MJ, Bindraban PS (2001) Physiology and modelling of traits in crop plants: implications for genetic improvement. Agric Syst 70:395-420. doi:10.1016/S0308-521X(01)00053-1

Boote KJ, Jones JW, Batchelor WD, Nafziger ED, Myers O (2003) Genetic coefficients in the CROPGRO-soybean model: links to field performance and genomics. Agron J 95:32-51. doi:10.2134/ agronj2003.3200

Brancourt-Hulmel M, Biarnès-Dumoulin V, Denis JB (1997) Points de repère dans l'analyse de la stabilité et de l'interaction génotypemilieu en amélioration des plantes. Agronomie 17:219-246. doi:10.1051/agro:19970403

Brancourt-Hulmel M, Lecomte C, Meynard JM (1999) A diagnosis of yield-limiting factors on probe genotypes for characterizing environments in winter wheat trials. Crop Sci 39:1798-1808. doi:10. 2135/cropsci1999.3961798x

Brancourt-Hulmel M, Denis JB, Lecomte C (2000) Determining environmental covariates which explain genotype environment interaction in winter wheat through probe genotypes and biadditive factorial regression. Theor App Genet 100:285-298. doi:10.1007/ s001220050038

Brisson N, Ruget F, Gate P, Lorgeou J, Nicoullaud B, Tayot X, Plenet D, Jeuffroy MH, Bouthier A, Ripoche D, Mary B, Justes E (2002) STICS: a generic model for simulating crops and their water and nitrogen balances. II. Model validation for wheat and maize. Agronomie 22:69-92. doi:10.1051/agro:2001005

Casadebaig P, Debaeke P, Lecoeur J (2008) Thresholds for leaf expansion and transpiration response to soil water deficit in a range of sunflower genotypes. Eur J Agr 28:646-654. doi:10.1016/j.eja. 2008.02.001

Casadebaig P, Guilioni L, Lecoeur J, Christophe A, Champolivier L, Debaeke P (2011) SUNFLO, a model to simulate genotypespecific performance of the sunflower crop in contrasting environments. Agric For Meteorol 151:163-178. doi:10.1016/j.agrformet. 2010.09.012

Chapman SC (2008) Use of crop models to understand genotype by environment interactions for drought in real-world and simulated plant breeding material. Euphytica 161:195-208. doi:10.1007/ s10681-007-9623-Z

Chapman SC, Hammer GL, Butler DG, Cooper M (2000) Genotype by environment interactions affecting grain sorghum. III. Temporal sequences and spatial patterns in the target population of environments. Aust J Agric Res 51:223-233. doi:10. 1071/AR99022

Chapman SC, Cooper M, Hammer GL (2002) Using crop simulation to generate genotype by environment interaction effects for sorghum in water-limited environments. Aust J Agric Res 53:379-389. doi:10.1071/AR01070
Chapman S, Cooper M, Podlich D, Hammer GL (2003) Evaluating plant breeding strategies by simulating gene action and dryland environment effects. Agron J 95:99-113. doi:10.2134/agronj2003. 9900

Chenu K, Cooper M, Hammer GL, Mathews KL, Dreccer MF, Chapman SC (2011) Environment characterization as an aid to wheat improvement: interpreting genotype-environment interactions by modelling water-deficit patterns in North-Eastern Australia. J Exp Bot 62:1743-1755. doi:10.1093/jxb/erq459

Colson J, Bouniols A, Jones JW (1995) Soybean reproductive development: Adapting a model for european cultivars. Agron J 87:11291139. doi:10.2134/agronj1995.00021962008700060015x

Cooper M, Hammer GL (1996) Plant adaptation and crop improvement. CAB International, Wallingford, UK

Cox MC, Qualset CO, Rains DW (1986) Genetic-variation for nitrogen assimilation and translocation in wheat. 3. Nitrogen translocation in relation to grain-yield and protein. Crop Sci 26:737-740. doi:10.2135/cropsci1986.0011183X002600040022x

Debaeke P (2004) Scenario analysis for cereal management in waterlimited conditions by the means of a crop simulation model (STICS). Agronomie 24:315-326. doi:10.1051/agro:2004035

Debaeke P, Nolot JM (2006) A rule-based method for the development of crop management systems applied to grain sorghum in southwestern France. Agric Sys 90:180-201. doi:10.1016/j.agsy.2006. 01.001

Debaeke P, Casadebaig P, Mestries E, Palleau JP, Salvi F, Bertoux V, Uyttewaal V (2011) Evaluer et valoriser les interactions variétémilieu-conduite en tournesol. Innovations Agronomiques 14:7790

Desclaux D (1996) De l'intérêt de génotypes révélateurs de facteurs limitants dans l'analyse des interactions génotype*milieu chez le soja (Glycine max. L. Merill). Thèse de doctorat. Institut national polytechnique de Toulouse, Toulouse, France.

Donald CM (1968) The breeding of crop ideotypes. Euphytica 17:385403. doi:10.1007/BF00056241

Epinat-Le Signor C, Dousse S, Lorgeou J, Denis JB, Bonhomme R, Carolo P, Charcosset A (2001) Interpretation of genotype $\times$ environment interactions for early maize hybrids over 12 years. Crop Sci 41:663-669. doi:10.2135/cropsci2001.413663x

Fargue A, Colbach N, Meynard JM (2005) Introduction of genotypic effects into GeneSys-rape: the example of height and male sterility. Agric Ecosys Env 108:318-328. doi:10.1016/j.agee.2005.01.010

Fargue A, Colbach N, Pierre J, Picault H, Renard M, Meynard JM (2006) Predictive study of the advantages of cleistogamy in oilseed rape in limiting unwanted gene flow. Euphytica 151:1-13. doi:10.1007/s10681-005-9005-3

Foucteau V, El Daouk M, Baril C (2001) Interpretation of genotype by environment interaction in two sunflower experimental networks. Theor App Genet 102:327-334. doi:10.1007/s001220051649

Goyne PJ, Meinke H, Milroy SP, Hammer GL, Hare JM (1996) Development and use of a barley crop simulation model to evaluate production management strategies in north-eastern Australia. Aust J Agric Res 47:997-1015. doi:10.1071/AR9960997

Hammer GL, Goyne PJ, Woodruff DR (1982) Phenology of sunflower cultivars. III. Models for prediction in field environments. Aust J Agric Res 33:251-261. doi:10.1071/AR9820263

Hammer GL, Butler DG, Muchow RC, Meinke H (1996) Integrating physiological understanding and plant breeding via crop modelling and optimization. In: Cooper M, Hammer GL (eds) Plant adaptation and crop improvement. CAB International, Wallingford (UK), pp 419-441

Hammer GL, Kropff MJ, Sinclair TR, Porter JR (2003) Future contributions of crop modeling-from heuristics and supporting decision making to understanding genetic regulation and aiding crop improvement. Eur J Agr 18:15-31. doi:10.1016/S1161-0301(02) 00093-X 
Hammer GL, van Oosterom E, McLean G, Chapman SC, Broad I, Harland P, Muchow RC (2010) Adapting APSIM to model the physiology and genetics of complex adaptive traits in field crops. $\mathrm{J}$ Exp Bot 61:2185-2202. doi:10.1093/jxb/erq095

Hoogenboom G, White JW, Acosta-Gallegos J, Gaudiel RG, Myers JR, Silbernagel MJ (1997) Evaluation of a crop simulation model that incorporates gene action. Agron J 89:613-620. doi:10.2134/ agronj1997.00021962008900040013x

Hoogenboom G, White JW, Messina CD (2004) From genome to crop: integration through simulation modeling. Field Crops Res 90:145163. doi:10.1016/j.fcr.2004.07.014

Houlès V, Mary B, Guérif M, Makowski D, Justes E (2004) Evaluation of the ability of the crop model STICS to recommend nitrogen fertilization rates according to agro-environmental criteria. Agronomie 24:339-349. doi:10.1051/agro:2004036

Hunt LA, Reynolds MP, Sayre KD, Rajaram S, White JW, Yan W (2003) Crop modeling and the identification of stable coefficient that may reflect significant groups of genes. Agron J 95:20-31. doi:10.2134/agronj2003.2000

Irmak A, Jones JW, Mavromatis T, Welch SM, Boote KJ, Wilkerson GG (2000) Evaluating methods for simulating soybean cultivar responses using cross validation. Agron J 92:1140-1149. doi:10. 2134/agronj2000.9261140x

Jackson P, Robertson M, Cooper M, Hammer G (1996) The role of physiological understanding in plant breeding, from a breeding perspective. Field Crops Res 49:11-37. doi:10.1016/S03784290(96)01012-X

Jeuffroy MH, Barré C, Bouchard C, Demotes-Mainard S, DevienneBarret F, Girard ML, Recous S (2000) Fonctionnement d'un peuplement de blé en conditions de nutrition azotée suboptimale. In: Bonhomme R, Maillard P (eds) Fonctionnement des peuplements végétaux sous contraintes environnementales. INRA, Paris, Les Colloques n 93 , pp 289-304

Jeuffroy MH, Barbottin A, Jones JW, Lecoeur J (2006) Crop-models with genotype parameters. In: Wallach D, Makowski D, Jones JW (eds) Working with dynamic crop models - evaluation, analysis, parameterization and applications. Elsevier, Amsterdam (The Netherlands), pp 281-307

Jeuffroy MH, Vocanson A, Roger-Estrade J, Meynard JM (2012) The use of models at field and farm levels for the ex ante assessment of new pea genotypes. Eur J Agr 42:68-78. doi:10.1016/j.eja.2012. 04.005

Lamboni M, Makowski D, Lehuger S, Gabrielle B, Monod H (2009) Multivariate global sensitivity analysis for dynamic crop models. Field Crops Res 113:312-320. doi:10.1016/j.fcr.2009.06.007

Le May C, Schoeny A, Tivoli B, Ney B (2005) Improvement and validation of a pea crop growth model to simulate the growth of cultivars infected with Ascochyta blight (Mycosphaerella pinodes). Eur J Plant Pathol 112:1-12. doi:10.1007/s10658004-5272-4

Lecomte C (2005) “L'évaluation expérimentale des innovations variétales. Proposition d'outils d'analyse de l'interaction genotype - milieu adaptés à la diversité des besoins et des contraintes des acteurs de la filière semences," Thèse INA P-G, Paris

Lecomte C, Prost L, Cerf M, Meynard JM (2010) Basis for designing a tool to evaluate new cultivars. Agron Sustain Dev 30:667-677. doi:10.1051/agro/2009042

Leenhardt D, Trouvat JL, Gonzalès G, Pérarnaud V, Prats S, Bergez JE (2004) Estimating irrigation demand for water management on a regional scale: I. ADEAUMIS, a simulation platform based on bio-decisional modelling and spatial information. Agric Water Manag 68:207-232. doi:10.1016/j.agwat.2004.04.004

Liu WTH (1989) Application of CERES-MAIZE model to yield prediction of Brazilian maize hybrid. Agric Forest Meteor 45:299 312. doi:10.1016/0168-1923(89)90050-6
Loyce C, Rellier JP, Meynard JM (2002a) Management planning for winter wheat with multiple objectives (1): the BETHA system. Agric Syst 72(1):9-31. doi:10.1016/S0308-521X(01)00064-6

Loyce C, Rellier JP, Meynard JM (2002b) Management planning for winter wheat with multiple objectives (2): ethanol-wheat production. Agric Syst 72(1):33-57. doi:10.1016/S0308-521X(01) 00065-8

Loyce C, Meynard JM, Bouchard C, Rolland B, Lonnet P, Bataillon P, Bernicot MH, Bonnefoy M, Charrier X, Debote B, Demarquet T, Duperrier B, Félix I, Heddadj D, Leblanc O, Leleu M, Mangin P, Méausoone M, Doussinault G (2008) Interaction between cultivar and crop management effects on winter wheat diseases, lodging, and yield. Crop Prot 27:1131-1142. doi:10.1016/j.cropro.2008. 02.001

Makowski D, Hillier J, Wallach D, Andrieu B, Jeuffroy MH (2006a) Parameter estimation for crop models. In: Makowski D, Jones JW, Wallach D (eds) Working with dynamic crop models. Elsevier, New York, pp 101-149

Makowski D, Naud C, Jeuffroy MH, Barbottin A, Monod H (2006b) Global sensitivity analysis for calculating the contribution of genetic parameters to the variance of crop model predictions. Reliab Eng Syst Saf 91:1142-1147. doi:10.1016/j.ress.2005.11.015

Makowski D, Doré T, Monod H (2007) A new method to analyse relationships between yield components with boundary lines. Agron Sustain Dev 27:119-128. doi:10.1051/agro:2006029

Matthews RB (2002) Crop genotype improvement. In: Matthews R, Stephens W (eds) Crop-soil simulation models: applications in developing countries. CAB International, Wallingford (UK), pp $13-28$

Mavromatis T, Boote KJ, Jones JW, Irmak A, Shinde D, Hoogenboom G (2001) Developing genetic coefficients for crop simulation models with data from crop performance trials. Crop Sci 41:40 51. doi:10.2135/cropsci2001.41140x

Mavromatis T, Boote KJ, Jones JW, Wilkerson GG, Hoogenboom G (2002) Repeatability of model genetic coefficients derived from soybean performances trials across different states. Crop Sci 42:76-89. doi:10.2135/cropsci2002.7600

Messina CD, Boote KJ, Löffler C, Jones JW, Vallejos CE (2006) Model-assisted genetic improvement of crops. In: Wallach D, Makowski D, Jones JW (eds) Working with dynamic crop models - evaluation, analysis, parameterization and applications. Elsevier, Amsterdam (The Netherlands), pp 309-335

Meynard JM, Jeuffroy MH (2002) Progrès génétique et agriculture durable. Le Sélectionneur Français 53:69-82

Muchow RC, Hammer GL, Carberry PS (1991) Optimizing crop and cultivar selection in response to climatic risk. In: Muchow RC, Bellamy JA (eds) Climatic risk in crop production-models and management for the semiarid tropics and subtropics. $\mathrm{CAB}$ International, Wallingford (UK), pp 235-262

Muchow RC, Hammer GL, Vanderlip RL (1994) Assessing climatic risk to sorghum production in water-limited subtropical environments. II. Effects of planting date, soil water at planting, and cultivar phenology. Field Crops Res 36:235-246. doi:10.1016/ 0378-4290(94)90115-5

Naud C, Makowski D, Jeuffroy MH (2007) An interacting particle filter to improve model-based predictions of nitrogen nutrition index for winter wheat. Ecol Model 207:251-263. doi:10.1016/j.ecolmodel. 2007.05.003

Olesen JE, Hansen PK, Berntsen J, Christensen S (2004) Simulation of above-ground suppression of competing species and competition tolerance in winter wheat varieties. Field Crops Res 89:263-280. doi:10.1016/j.fcr.2004.02.005

Piper EL, Boote KJ (1993) Temperature and cultivar effects on soybean seed oil and protein concentrations. J Am Oil Chem Soc 76:12331241. doi:10.1007/s11746-999-0099-y 
Reymond M (2001) Variabilité génétique des réponses de la croissance foliaire du maïs à la température et au déficit hydrique. Combinaison d'un modèle écophysiologique et d'une analyse QTL. Thèse de l'ENSAM, Montpellier

Reymond M, Muller B, Leonardi A, Charcosset A, Tardieu F (2003) Combining quantitative trait loci analysis and an ecophysiological model to analyze the genetic variability of the responses of maize leaf growth to temperature and water deficit. Plant Physiol 131:664-675

Richards RA (1996) Defining selection criteria to improve yield under drought. Plant Growth Regul 20:157-166. doi:10.1007/ BF00024012

Saulescu NN, Kronstad WE (1995) Growth simulation outputs for detection of differential cultivar response to environmental factors. Crop Sci 35:773-778. doi:10.2135/cropsci1995.0011183X $003500030023 \mathrm{x}$

Sedgley RH (1991) An appraisal of the Donald ideotype after 21 years. Field Crops Res 26:93-112. doi:10.1016/0378-4290(91)90031-P

Semenov MA, Martre P, Jamieson PD (2009) Quantifying effects of simple wheat traits on yield in water-limited environments using a modelling approach. Agric For Metor 149:1095-1104. doi:10. 1016/j.agrformet.2009.01.006

Shorter R, Lawn RJ, Hammer GL (1991) Improving genotypic adaptation in crops - a role for breeders, physiologists and modellers. Exp Agric 27:155-175. doi:10.1017/S0014479700018810

Sinclair TR, Muchow RC (2001) System analysis of plant traits to increase grain yield on limited water supplies. Agron J 93:263270. doi:10.2134/agronj2001.932263x

Singels A, de Jager JM (1991) Determination of optimum wheat cultivar characteristics using a growth model. Agric Syst 37:25-38. doi:10.1016/0308-521X(91)90045-C

Stapper M, Harris HC (1989) Assessing the productivity of wheat genotypes in a Mediterranean climate, using a crop-simulation model. Field Crops Res 20:129-152. doi:10.1016/0378-4290(89) 90057-9

Suriharn B, Patanothai A, Boote KJ, Hoogenboom G (2011) Designing a peanut ideotype for a target environment using the CSMCROPGRO-Peanut model. Crop Sci 51:1887-1902. doi:10. 2135/cropsci2010.08.0457

Travasso MI, Magrin GO (1998) Utility of CERES-barley under Argentine conditions. Field Crops Res 57:329-333. doi:10.1016/ S0378-4290(98)00079-3

Van Eeuwijk FA, Keizer LCP, Bakker JJ (1995) Linear and bilinear models for the analysis of multienvironment trials: II. An application to data from the Dutch Maize Variety Trials. Euphytica 84:9 22. doi:10.1007/BF01677552

Vear F, Bony H, Joubert G, Tourvieille de Labrouhe D, Pauchet I, Pinochet X (2003) The results of 30 years of sunflower breeding for France. OCL 10:66-73

Villalobos FJ, Hall AJ, Richie JT, Orgaz F (1996) OILCROP-SUN: a development, growth, and yield model of the sunflower crop.
Agron J 88:403-415. doi:10.2134/agronj1996.00021962008800 $030008 \mathrm{x}$

Voltas J, van Eeuwijk FA, Sombrero A, Lafarga A, Igartua E, Romagosa I (1999a) Integrating statistical and ecophysiological analyses of genotype by environment interaction for grain filling of barley I.: Individual grain weight. Field Crops Res 62:63-74. doi:10.1016/ S0378-4290(99)00006-4

Voltas J, van Eeuwijk FA, Araus JL, Romagosa I (1999b) Integrating statistical and ecophysiological analyses of genotype by environment interaction for grain filling of barley II.: Grain growth. Field Crops Res 62:75-84. doi:10.1016/S0378-4290(99)00007-6

Wallach D, Goffinet B (1987) Mean squared error of prediction in models for studying ecological and agronomic systems. Biometrics 43:561-573

Wallach D, Goffinet B (1989) Mean squared error of prediction as a criterion for evaluating and comparing systems models. Ecol Model 44:299-306. doi:10.1016/0304-3800(89)90035-5

Wallach D, Goffinet B, Bergez JE, Debaeke P, Leenhardt D, Aubertot JN (2001) Parameter estimation for crop models: a new approach and application to corn model. Agron J 93:757-766. doi:10.2134/ agronj2001.934757x

Whisler FD, Acock B, Baker DN, Fye RE, Hodges HF, Lambert JR, Lemmon HE, McKinion JM, Reddy VR (1986) Crop simulation models in agronomic systems. Adv Agron 40:141-208. doi:10. 1016/S0065-2113(08)60282-5

White JW, Hoogenboom G (1996) Simulating effects of genes for physiological traits in a process-oriented crop model. Agron $\mathrm{J}$ 88:416-422. doi:10.2134/agronj1996.00021962008800030009x

Yin X, Struik PC (2010) Modelling the crop: from system dynamics to systems biology. J Exp Bot 61:2171-2183. doi:10.1093/jxb/ erp375

Yin X, van Laar HH (2005) Crop systems dynamics: an ecophysiological simulation model for genotype-by-environment interactions. Wageningen Academic Publishers, Wageningen

Yin X, Kropff MJ, Goudriaan J, Stam P (2000) A model analysis of yield differences among recombinant inbreed lines in barley. Agron J 92:114-120. doi:10.2134/agronj2000.921114x

Yin X, Stam P, Kropff MJ, Schapendonk AHCM (2003) Crop modeling, QTL mapping, and their complementary role in plant breeding. Agron J 95:90-98. doi:10.2134/agronj2003.9000

Zhang XY (2005) Modélisation de la réponse des variétés de blé au niveau d'intensification. Influence de la pression de maladies foliaires, Thèse INA P-G, Paris

Zhang XY, Loyce C, Meynard JM, Savary S (2006) Characterization of multiple disease systems and cultivar susceptibilities for the analysis of yield losses in winter wheat. Crop Prot 25:1013-1023. doi:10.1016/j.cropro.2006.01.013

Zhang XY, Loyce C, Meynard JM, Monod H (2007) Modeling the effects of cultivar resistance on yield losses of winter wheat in natural multiple disease conditions. Eur J Agr 26:384-393. doi:10. 1016/j.eja.2006.12.004 